Gut, 1985, 26, 179-187

\title{
Diarrhoea and malabsorption in acquired immune deficiency syndrome: a study of four cases with special emphasis on opportunistic protozoan infestations
}

\author{
R MODIGLIANI, C BORIES, Y LE CHARPENTIER, \\ M SALMERON, B MESSING, A GALIAN, J C RAMBAUD, A LAVERGNE, \\ B COCHAND-PRIOLLET, AND I DESPORTES
}

From the Department of Gastroenterology, Saint-Lazare Hospital, Paris, the Department of Pathology, Lariboisière Hospital, and the Protozoa Cytophysiology Laboratory, Paris, France

SUMMARY Chronic diarrhoea is frequent in acquired immune deficiency syndrome (AIDS) but has been poorly investigated so far. We report four patients with AIDS in whom diarrhoea and malabsorption were outstanding features, and who underwent extensive digestive investigations. Diarrhoea was a presenting symptom in all subjects and was of secretory type in three of them. D-xylose and vitamin $B_{12}$ were malabsorbed in all cases; steatorrhea was found in the two patients who could ingest significant amounts of fat. Faecal $\alpha 1$-antitrypsin clearance was increased in all subjects. Search for digestive pathogens showed unusual protozoans in all patients: in case 1, optical and electron microscopy revealed the presence in the cytoplasm of villous enterocytes of Microsporidia protozoans still unreported in AIDS. Stool and jejunal fluid examination showed Isospora belli in case 2 and Cryptosporidium in cases 3 and 4 . On histological and ultrastructural study the former was localised in the cytoplasm of a few enterocytes and the latter was scattered throughout the villus and crypt brush border. Otherwise small intestinal histology only showed minor non-specific changes and the enterocytes were ultrastructurally normal. In patient 3 the slow marker intestinal perfusion technique showed a profuse fluid secretion in the duodenum and proximal jejunum. All patients needed prolonged total parenteral nutrition. Cryptosporidium and Microsporidia could not be eradicated despite multiple drug trials. Isospora belli was transiently cured by pyrimethamine-sulphadiazine. Only patient 2 is presently at home, and patients 1,3 , and 4 died after two, six, and nine months of total parenteral nutrition, respectively.

Diarrhoea has been recently recognised as a frequent symptom in the acquired immune deficiency syndrome (AIDS), especially in Haitian patients; ${ }^{2}$ however, its type and mechanism have not been investigated as yet. Within the last two years we had the opportunity to study four AIDS patients in whom diarrhoea and malabsorption were outstanding clinical features. The aim of the present paper is to report the detailed digestive investigations carried out in these patients in order to better characterise the digestive abnormalities in AIDS. It emphasises the frequency of unusual protozoan infestations of the gut and the usefulness of precise morphological studies (optical and electron

Address for correspondence: R Modigliani, Hôpital Saint-Lazare, 107 bis rue du Faubourg Saint-Denis, 75475 Paris Cedex 10, France.

Received for publication 24 April 1984 microscopy) of small intestinal biopsy specimens for their diagnosis.

\section{Case reports}

CASE 1

A 29 year old Haitian was admitted in February 1983 with a five month history of diarrhoea, weight loss $(17 \mathrm{~kg})$, fever, and epigastric pain. He had been living in France for four years. He denied any homosexual practice, drug addiction, and blood transfusion. On admission he experienced one to three bowel movements per day and 24 hour faecal output fluctuated between 0.3 and 1.41 of solid to watery non-bloody stools. Physical examination showed diffuse lymphadenopathy and acquired ichthyosis. Immunological investigations and 
intestinal function tests are summarised in Tables 1 and 2. Examination of stools - including the flotation technique ${ }^{3}$ - only found Giardia lamblia. Examination of the jejunal fluid was negative for parasites. Upper endoscopy (up to the proximal jejunum) and colonoscopy with ileoscopy were unremarkable. Small bowel barium radiography only showed parallel mucosal folds. Light microscopy studies of four duodeno-jejunal and two ileal biopsies (Fig. 1) showed in addition to minor non-specific mucosal changes (partial villous atrophy and mild inflammatory infiltrate of the lamina propria), small $(1-5 \mu \mathrm{m})$ round or ovoid basophilic bodies which were variably stained by Giemsa, Grocott, and Ziehl stains. They were seen in about one half of villous enterocytes, mainly in the apical area of the villus; they were exclusively located in the supranuclear portion of the cytoplasm of these cells. They were diagnosed as Microsporidia under the electron microscope on the following characteristic features: ${ }^{45}$ (a) absence of mitochondria; (b) various stages (Fig. 2) of sporogenesis (uni or multinucleated sporonts, uninucleated sporoblast and spores); (c) highly specific coiled polar filament (Fig. 3). No parasitophorous vacuole was seen. Furthermore an abnormal accumulation of neutral fat was found within dilated intercellular spaces of the epithelium and in perivascular areas of the lamina propria. Gastric, rectal, and colonic biopsies were normal. No viral particle was seen in the digestive biopsy specimens. Pyrimethamine (50 $\mathrm{mg}$ daily $\times 5$ days), sulphadiazine $(2 \mathrm{~g}$ daily $\times 15$ days $)$ and metronidazole $(1.5 \mathrm{~g}$ daily $\times 7$ days $)$ were administered; giardiasis was eradicated but

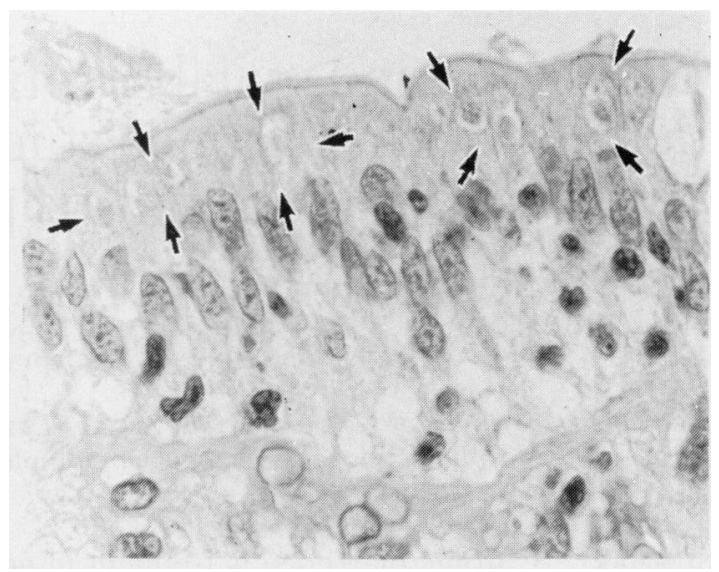

Fig. 1 Case 1. Duodenal biopsy. Numerous microsporidians in the supranuclear area of villous enterocytic epithelium (arrows) (haematoxylin-eosin $\times 1100$ original magnification).

diarrhoea and intestinal function tests did not improve. Several extradigestive opportunistic infections (diffuse facial ulcerations caused by Herpes simplex virus, Mycobacterium kansasii pneumonia, Pneumocystis carinii and cytomegalovirus lung infection) and unexplained bouts of fever occurred repeatedly and were treated by multiple oral and parenteral antibiotics. Finally he died 16 months after the onset of the disease. Necropsy revealed in addition Kaposi's sarcoma of inguinal lymph nodes, lung aspergillosis and total destruction of adrenal glands by fibrosis and necrosis.

Table 1 Immunological investigations.

\begin{tabular}{|c|c|c|c|c|c|c|c|c|}
\hline & \multirow{2}{*}{$\begin{array}{l}\text { Absolute } \\
\text { lymphocyte } \\
\text { count }(n / \mu l)\end{array}$} & \multicolumn{3}{|c|}{ Lymphocyte subsets } & \multirow[b]{2}{*}{ Skin tests* } & \multirow{2}{*}{$\begin{array}{l}\text { Lymphocyte } \\
\text { response to } \\
\text { non-specific } \\
\text { mitogenst }\end{array}$} & \multirow{2}{*}{$\begin{array}{l}\text { Lymphocyte } \\
\text { response to } \\
\text { specific } \\
\text { mitogens } \ddagger\end{array}$} & \multirow{2}{*}{$\begin{array}{l}\text { Serum } \\
\text { immunoglobulins } \\
(\mathrm{g} / \mathrm{l})\end{array}$} \\
\hline & & $\%$ & $\begin{array}{l}\% \\
O K T 8\end{array}$ & $\begin{array}{l}\text { ratio } \\
\text { OKT4/OKT8 }\end{array}$ & & & & \\
\hline Patient 1 & $80-1580$ & 5 & 68 & $0 \cdot 07$ & 0 & 0 & 0 & $\begin{array}{l}\operatorname{IgG}=32 \cdot 1 \\
\operatorname{IgA}=7 \cdot 35 \\
\operatorname{IgM}=2 \cdot 3 \\
\operatorname{IgG}=20 \cdot 4\end{array}$ \\
\hline Patient 2 & $320-1470$ & 4 & 56 & $0 \cdot 07$ & 0 & + & 0 & $\begin{array}{l}\operatorname{IgA}=9 \cdot 9 \\
\operatorname{IgM}=2 \cdot 2 \\
\operatorname{IgG}=14 \cdot 7\end{array}$ \\
\hline Patient 3 & $150-2050$ & 2 & 60 & $0 \cdot 03$ & 0 & + & 0 & $\begin{array}{l}\operatorname{IgA}=5.9 \\
\operatorname{lgM}=2.9 \\
\operatorname{IgG}=12.4\end{array}$ \\
\hline Patient 4 & $375-1360$ & 4 & 80 & $0 \cdot 05$ & 0 & $\downarrow$ & $\mathrm{ND} \S$ & $\begin{array}{l}\operatorname{Ig} A=4.8 \\
\operatorname{IgM}=1.6\end{array}$ \\
\hline
\end{tabular}

* Tuberculin, candidin, streptokinase, trychophyton, tetanus, diptheria and proteus antigens. + Phytohacmagglutinin, pokeweed mitogen and concavalin $\mathrm{A}$. $\ddagger$ Tuberculin, candidin, varidase, $\mathrm{CMV}$ and tetanus antigens. $\S \mathrm{ND}=$ not done, 0 , $\downarrow$ and + mean respectively negative, diminished and normal responses to all the antigens tested. 
Table 2 Intestinal function tests.

\begin{tabular}{|c|c|c|c|c|c|c|c|}
\hline & \multirow{2}{*}{$\begin{array}{l}D-x y l o s e^{*} \\
N>1.66 \mathrm{mmol} / \mathrm{l}\end{array}$} & \multirow{2}{*}{$\begin{array}{l}\text { Faecal fat } \\
N<21.6 \mathrm{mmol} / \mathrm{d}\end{array}$} & \multirow{2}{*}{$\begin{array}{l}\text { Schilling test with } \\
\text { intrinsic factor } \\
(N>10 \%)\end{array}$} & \multirow{2}{*}{$\begin{array}{l}\text { Alpha-1-antitrypsin } \\
\text { clearance } \\
(N<15 \mathrm{ml} / \mathrm{d})\end{array}$} & \multicolumn{2}{|c|}{$\begin{array}{l}\text { Stool electrolytes } \neq \\
(\mathrm{mM} / \text { /litre })\end{array}$} & \multirow{2}{*}{$\begin{array}{l}\text { Stool } \neq \\
\text { osmolality } \\
(\mathrm{mOsm} / \mathrm{kg})\end{array}$} \\
\hline & & & & & $\mathrm{Na}$ & $K$ & \\
\hline Patient 1 & $0 \cdot 53$ & $60 \cdot 5$ & 3 & 57 & ND§ & ND & ND \\
\hline $\begin{array}{l}\text { Patient } 2 \\
\quad \text { initial values } \\
\text { After eradication }\end{array}$ & $0 \cdot 26$ & $86 \cdot 4$ & 3 & 112 & 73 & 31 & ND \\
\hline of I belli & $2 \cdot 20$ & $20 \cdot 9$ & 25 & $32 \cdot 5$ & ND & ND & ND \\
\hline Patient 3 & $0 \cdot 40$ & $2 \cdot 15^{\dagger}$ & 3 & 45 & 68 & 63 & 299 \\
\hline Patient 4 & 0.46 & $9 \cdot 36{ }^{\dagger}$ & $0 \cdot 3$ & 28 & 88 & 51 & 297 \\
\hline
\end{tabular}

* Blood D-xylose $120 \mathrm{~min}$ after $25 \mathrm{~g}$ oral load. $†$ Low and not controlled lipid ingestion. $\ddagger$ These data were measured during fasting. $\S \mathrm{ND}=$ not done.

\section{CASE 2}

A 30 year old man, living in Green-Cape Island, first presented in January 1982 with diarrhoea and intermittent fever. Within the ensuing 18 months diarrhoea persisted, he lost $23 \mathrm{~kg}$ in weight and developed typhoid fever, Giardiasis intestinalis, Salmonella enteritidis, septicaemia, and Pneumococcus pneumonia. The patient was referred to us in June 1983: he appeared chronically ill and dehydrated. He denied homosexuality, drug addiction, and blood transfusion; physical examination was normal. He experienced 8-10 watery non-bloody bowel movements per day; stool volume ranged from 1-6 1 per day (average: 21 ) when he was eating and was not markedly reduced by fasting (average: 1.3 l). Immunological and intestinal function tests are shown in Tables 1 and 2 .

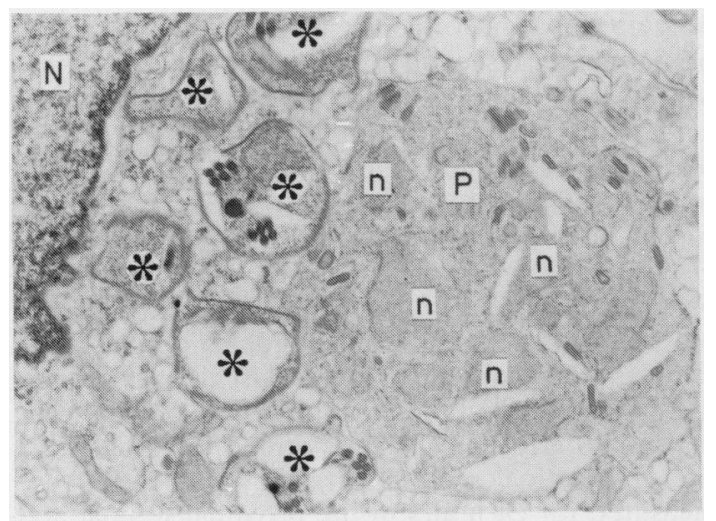

Fig. 2 Case 1. Portion of an enterocyte with its nucleus (N) and, in the cytoplasm two developmental stages of microsporidians: one multinucleated $(n)$ plasmod $(P)$ and 6 mononucleated sporoblasts $\left(^{*}\right)$ (electron microscopy $\times 19000)$.
Additional routine blood tests were normal. Jejunal aspirate and stool examinations for parasites showed Isospora belli oocysts; Candida albicans was also present in the stools. Bacterial count in the jejunal fluid was normal. Upper digestive endoscopy showed oesophageal candidiasis which was confirmed by biopsy; colonoscopy with ileoscopy and small bowel barium radiographs were normal. Histological examination of five duodenojejunal and one ileal biopsy specimens showed villi of normal or slightly reduced height, with a moderately increased lamina propria infiltrate; in addition a few (less than three per villus) Isospora belli maturing schizonts with their merozoites [1-3 elongated $(8 \times 3 \mu \mathrm{m})]$ bodies, within a vacuole at the basal pole of villi enterocytes were seen (Fig. 4). The presence of Isospora belli was confirmed by electron microscopy

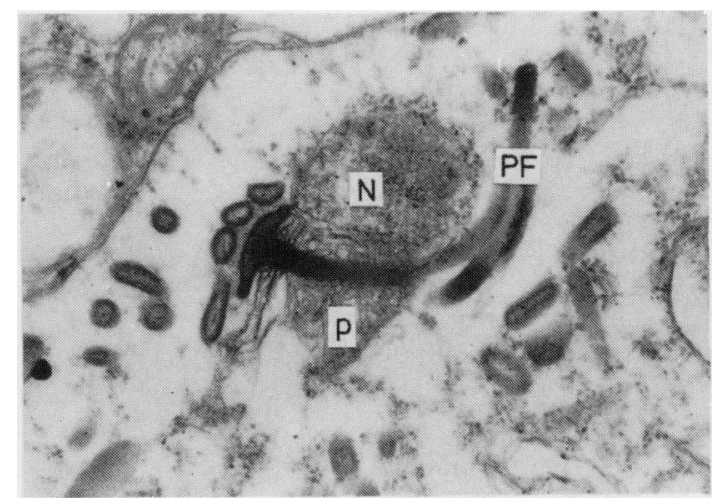

Fig. 3 Case 1. Part of a sporogonial microsporidian plasmod showing the juxtanuclear origin of polar filament (PF). $N=$ nucleus. $P=$ polaroplast. (Electron microscopy $\times 50000)$. 


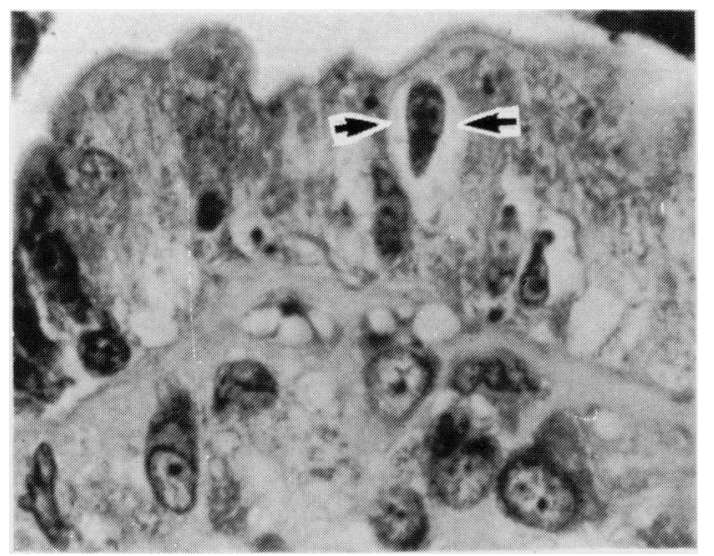

Fig. 4 Case 2. Duodenal biopsy. Two merozoites of Isospora belli in villous enterocytic epithelium (arrows). (May Grunwald Giemsa ×1000).

(Fig. 5). Gastric, colonic, and rectal biopsies were normal. No viral particle was seen on the gastrointestinal biopsies. The patient received a three week course of total parenteral nutrition and the following drugs were given orally: metronidazole $(0.75 \mathrm{~g}$ daily $\times 5$ days $)$, amphotericin B $(3 \mathrm{~g}$ daily $\times$ 40 days), pyrimethamine (50 mg daily $\times 26$ days $)$, suphadiazine $(4.5 \mathrm{~g}$ daily $\times 26$ days). The diarrhoea disappeared progressively and two months later the patient had gained $23 \mathrm{~kg}$; absorption tests had returned to normal (Table 2), Isospora belli had disappeared from the stools, duodenal aspirate, and

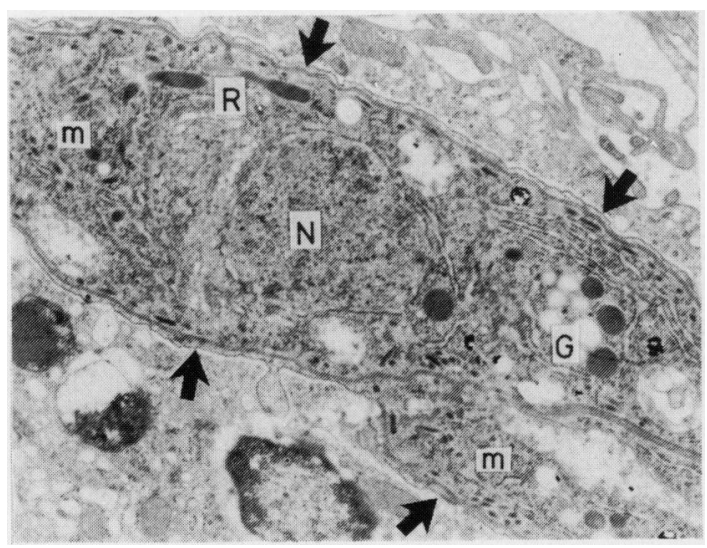

Fig. 5 Case 2. Intra enterocytic merozoites of Isospora belli (arrows) showing nucleus $(N)$, rhoptries $(R)$, micronemas $(M)$ and granules $(G)$. (Electron microscopy $\times 12500)$. duodenojejunal mucosa; he was discharged in July 1983. In September 1983 he was readmitted for pulmonary tuberculosis and recurrence of diarrhoea. Isospora belli was present in stools and small intestinal biopsies. He responded again to a course of pyrimethamine and sulphadiazine.

CASE 3

This case has been reported in detail elsewhere. ${ }^{6}$ Briefly this 31 year old Frenchman presented in April 1982 with diarrhoea (3-7 daily stools), vomiting, abdominal pain, and weight loss $(10 \mathrm{~kg})$ of eight months' duration. The only risk factor for AIDS was a trip to French West Indies and Haiti where he received blood transfusion after a road accident in 1978. On admission physical examination was normal; the daily stool output averaged $0.720 \mathrm{l}$ when he was eating and was not influenced by prolonged total parenteral nutrition (average: 1 l). Routine blood tests were normal. Immunological and intestinal function tests are shown in Tables 1 and 2; Standard stool examination for parasites only found Candida albicans but thereafter Cryptosporidium sp oocysts were seen in faecal smears stained by modified Ziehl-Neelsen technique. ${ }^{7}$ The protozoan was also found in the jejunal fluid. Upper digestive endoscopy showed whitish granulations of the duodenal mucosa; colonoscopy was normal and small bowel barium radiography showed moderate mucosal fold coarsening. Multiple duodenojejunal biopsy specimens showed normal villous height or partial villous atrophy; crypts were of normal size with occasional indications of cryptitis. There was a dense inflammatory infiltrate of the lamina propria consisting mainly of plasma cells with a few polymorphs and macrophages. Cryptosporidial organisms were seen (Fig. 6) as multiple round (2-4 $\mu \mathrm{m})$ basophilic bodies, variably stained by periodic acid/Schiff and Grocott's silver impregnation, scattered throughout the villus and crypt brush border in nearly all small intestinal biopsy specimens. Cryptosporidiosis was confirmed by electron microscopy (Fig. 7). Cryptosporidium $\mathrm{sp}$ protozoans were also found in some of the gastric biopsy specimens. Rectal and colonic biopsy samples were normal. No viral particle was seen in the gastrointestinal biopsy samples. A slow marker intestinal perfusion ${ }^{8}$ was performed to localise the site of intestinal secretion; fasting flow rates were measured for 24 hours in the proximal jejunal and distal ileum. Results are shown in Table 3. Numerous agents were given orally: metronidazole ( $1.5 \mathrm{~g}$ daily $\times 15$ days), amphotericin B ( $2 \mathrm{~g}$ daily $\times$ 75 days), nystatin (300 $000 \mathrm{U}$ daily $\times 23$ days), sulphamethoxazole trimethroprim (1600 mg and 320 


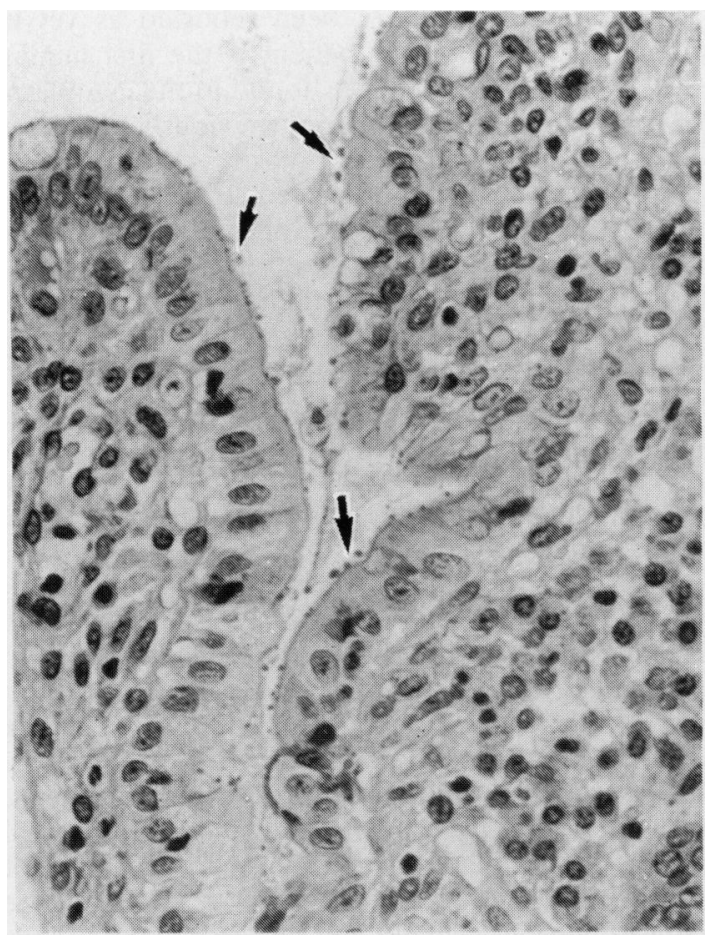

Fig. 6 Case 3: Jejunal biopsy. Numerous cryptosporidians attached to the brush border of enterocytes (arrows) (haematoxylin-eosin $\times 430$ ).

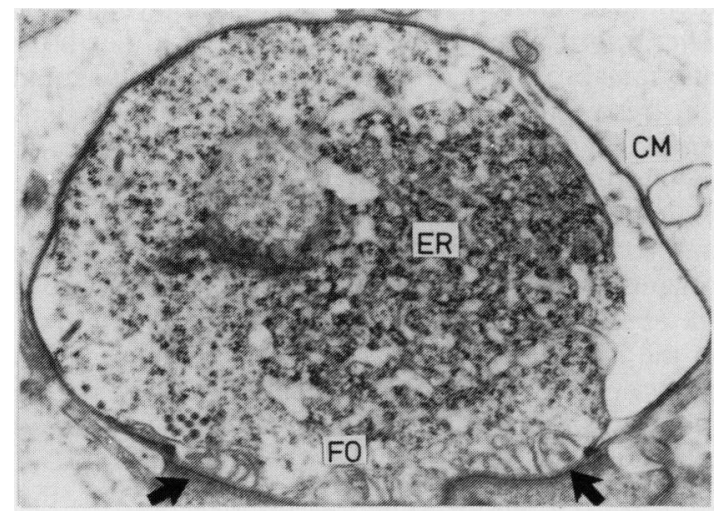

Fig. 7 Case 3. Trophozoite of Cryptosporidium in the apex of an enterocyte with characteristic junctional zone (arrows) and feeder organelle (FO). CM = cytoplasmic membrane of enterocyte. $E R=$ endoplasmic reticulum of trophozoite. (Electron microscopy $\times 35000$ ).
Table 3 Fasting 24 hour flow rate in proximal jejunum and at the ileocaecal junction, and stool output.

\begin{tabular}{llll}
\hline & \multicolumn{2}{c}{24 h flow rates } & \\
\cline { 2 - 3 } & $J^{*}$ & $I C^{*}$ & 24 h stool output \\
\hline Fluid (ml) & & & \\
Patient 3 & 11245 & 6432 & $1000 \dagger$ \\
Normal & $2650 \pm 806 \ddagger$ & $2246 \pm 403 \ddagger$ & $<300$ \\
Sodium (mmol) & & & \\
Patient 3 & 1619 & 751 & $47 \dagger$ \\
Normal & $361 \pm 92 \ddagger$ & $324 \pm 77 \ddagger$ & $<10$ \\
\hline
\end{tabular}

* J: proximal jejunum; IC = ileocaecal junction; the distal sampling point migrated from the ileum to the caecum 7 hours after onset of the experiment; hourly outputs measured successively at these 2 sites were identical and results were pooled as $24 \mathrm{~h}$ ileocaecal flow rates. + Average of daily faecal outputs during 7 days preceding the perfusion. $¥$ Mean $\pm 2 \mathrm{SD} ; 4$ normal subjects. ${ }^{8}$

mg daily $\times 5$ days $)$, paramomycin $(2 \mathrm{~g}$ daily $\times 26$ days), framycetin (900 mg daily $\times 13$ days $)$, pyrimethamine $(50 \mathrm{mg}$ daily $\times 27$ days $)$, and sulphadiazine ( $3 \mathrm{~g}$ daily $\times 27$ days); Candida albicans was eradicated but diarrhoea did not improve; Cryptosporidium persisted on repeated small bowel biopsies. While on total parenteral nutrition he continued to have vomiting, abdominal pain, and diarrhoea, and developed several episodes of Salmonella typhi murium septicaemias (for which he received multiple courses of antibiotics) and Toxoplasma gondii cerebral abcesses. $\mathrm{He}$ died suddenly on October 24, 1982. Permission for necropsy was not granted.

CASE 4

A 36 year-old Egyptian homosexual male was diagnosed as having AIDS complicated by cryptosporidiosis in another hospital. He was referred in August 1983 for total parenteral nutrition because of intractable chronic diarrhoea (10-15 watery stools per day), with hypokalaemia $(2.7 \mathrm{mM} / \mathrm{l})$, vomiting, weight loss (14 kg) and fever since December 1982. On admission his temperature was $38^{\circ} \mathrm{C}$; physical examination disclosed left axillary and inguinal lymphadenopathy and mild splenomegaly; daily stool volumes ranged from 1 to 2.51 (average: $1.7 \mathrm{l}$ ) when he was eating and averaged 1.31 on fasting. Routine blood tests were normal. Immunological and intestinal function tests are shown in Tables 1 and 2; glucose $(50 \mathrm{~g})$ breath test was normal. Stool examination for parasites confirmed the presence of Cryptosporidium oocysts and Candida albicans. Upper digestive endoscopy, colonoscopy, and small bowel barium radiography were normal. Seven duodenojejunal biopsy specimens showed the presence of Cryptosporidium with a histo- 
pathological and ultrastructural picture identical to that of patient 3. The parasite was also found on colonic biopsy specimens. No viral particle was seen in the gastrointestinal biopsy samples. The following drugs were tried orally: amprolium ( $1 \mathrm{~g}$ daily $\times 16$ days), sulphadimetoxine ( $1 \mathrm{~g}$ daily $\times$ seven days $)$, nystatin (4000 $000 \mathrm{U}$ daily $\times 16$ days), amphotericin B (3 g daily $\times$ five days). He also received several courses of parenteral antibiotics and ornidazole for unexplained fever. Candidosis disappeared from the stools but repeated small bowel biopsies showed persistent cryptosporidiosis and the diarrhoea did not improve. The patient died on 22 April, 1984.

\section{Discussion}

Our four patients met the criteria for AIDS: ${ }^{9}$ (1) They had a profound cellular immune deficiency with low counts of helper $T$ cells and decreased OKT4/OKT8 lymphocyte ratios. (2) They had no other cause for this immunological defect. Patients 1 and 4 belonged to classical high risk groups for AIDS $^{9}$ (Haitians and homosexuals); patient 3 probably acquired the disease by receiving Caribbean blood four years previously; living in Green Cape Island was the only detectable risk factor in patient 2: he represents the first example of AIDS from this island, but a few cases have been reported from Continental Africa. ${ }^{10}$

Diarrhoea was a major clinical feature in our patients, leading in cases 2,3 , and 4 to hypokalaemia and requiring massive intravenous fluid and ion replacement. This symptom seems to be very frequent in AIDS $^{12}$ (90\% of Haitian patients with opportunistic infections). ${ }^{2}$ On the contrary malabsorption has not been clearly documented so far in AIDS except in one case where it was associated with a disseminated Mycobacterium avium - intracellulare infection that mimicked Whipple's disease ${ }^{11}$ histologically. Our results do suggest that severe malabsorption (involving fat, D-xylose, and vitamin $\mathrm{B}_{12}$ ) is frequent in AIDS with diarrhoea, even in the absence of gut infestation with atypical mycobacteria; it may require prolonged courses of total parenteral nutrition. Furthermore our four patients had an exudative enteropathy (heretofore undescribed in AIDS) as shown by the high values of $\alpha 1$-antitrypsin faecal clearance. Of special interest is the presence in our cases of uncommon (and in one case possibly undescribed) intestinal parasites.

Microsporidians represent a protozoan phylum that includes well known pathogens for arthropodes, fishes, ${ }^{12}$ and a few mammals ${ }^{13}$ and is characterised by the presence of a polar filament inside the spore.
Microsporidiosis has not been reported as yet in AIDS; furthermore our patient is the first human case where the parasite was found in the cytoplasm of enterocytes. The number of previously published cases of human microsporidiosis is a matter of debate ${ }^{14-16}$ but does not exceed seven. ${ }^{17-23}$ In fact only four case reports ${ }^{20-23}$ are reasonably well documented though only one $e^{22}$ includes an ultrastructural study: in three of them, the organism was found in brain, ${ }^{20}$ cornea, ${ }^{23}$ and the cytoplasm of pancreatic carcinomatous cells. ${ }^{21}$ The last patient ${ }^{22}$ was a four month old infant with thymic alymphoplasia who presented with diarrhoea; necropsy revealed disseminated microsporidiosis, involving gut smooth muscle, mesenteric ganglia and nerve fibres; enterocytes were apparently spared. The classification of Microsporidia remains uncertain; the organisms found in the human cases have been labelled as Nosema ${ }^{1521} 22$ or Encephalitozoon. ${ }^{20} 23$ Morphology of spores and sporogenesis observed in our case differs from that described for these genera of microsporidians: Nosema spores are binucleated $^{4} 515$ and Encephalitozoon sporogenesis, studied by electron microscopy in varied animal species $^{24}$ was found to take place by dropping of sporoblasts inside the cavity of a large parasitophorous vacuole, not seen in patient 1 . Thus the Microsporidia involved in our case may represent a new genus.

The diagnosis of microsporidiosis has been especially difficult in our patient: it was not found despite careful examination of stools and jejunal fluid; it may also be overlooked by light microscopy of gut biopsy samples because of its very small size (1-5 $\mu \mathrm{m})$, intracellular location, and poor tinctorial properties. Thus electron microscopy is essential for identification of this parasite. The role played by the Microsporidia in the pathogenesis of the diarrhoea and malabsorption of patient 1 is unclear. It should be stressed that the parasite inhabited many villous enterocytes, and that no other cause of malabsorption was found: there was no significant villous atrophy, nor ultrastructural lesion of the enterocytes (apart from the presence of the organism); eradication of giardiasis did not improve the absorption tests. The accumulation of neutral fat in the intercellular spaces of the epithelium and in perivascular areas of the lamina propria during fasting is intriguing and points to a disorder of lipid transport somewhere beyond the enterocyte.

Isospora belli is a protozoan located in the enterocyte cytoplasm and usually reported from the tropics; it may be responsible for chronic diarrhoea, malabsorption, and various degrees of villous atroph ${ }^{25}$ in immunocompetent subjects. It has also been reported, although rarely, in AIDS. ${ }^{26} 27$ In 
case 2 , diagnosis was easily made by examination of stools and jejunal fluid, and confirmed by careful histological examination of the duodenojejunal mucosa. Its pathogenicity is very likely ${ }^{25}$ and supported by our case 2 : diarrhoea and malabsorption disappeared in concert with the disappearance of Isospora belli from the gut and relapsed when the parasitosis recurred. The pathophysiology of the malabsorption in patient 2 , however, is unclear in the absence of severe villous changes observed by others $^{25}$ and with normal enterocytes on electron microscopy.

Cryptosporidium $s p$ is a protozoan that primarily inhabits the microvillus regions of epithelial cells. Until recently cryptosporidiosis was considered to be rare and to occur mainly in immunosuppressed patients. ${ }^{28-30}$ Over the last two years it has been frequently reported in AIDS patients with diarrhoea $^{31}$ and reached an incidence of $38 \%$ in a Haitian series. ${ }^{1}$ This tiny parasite is easily overlooked ${ }^{30}$ unless faecal smears are adequately stained $^{732}$ and histological sections of intestine examined at high magnification.

Cryptosporidiosis resists any form of therapy in AIDS: it is thus impossible to know whether its eradication would cure the diarrhoea. Several facts, however, do suggest that this parasite is causally related to diarrhoea. (1) Recent reports show that Cryptosporidium may be commonly found in the stools of immunocompetent subjects suffering from acute, self-limiting diarrhoea. ${ }^{3} 33$ (2) An outbreak of diarrhoeal cryptosporidiosis has been reported in previously healthy subjects who were exposed to calves infected with Cryptosporidium; organisms isolated from these calves and patients could be experimentally transmitted to normal calves and cause diarrhoea. ${ }^{3}$ (3) In one case ${ }^{28}$ withdrawal of immunosuppressive therapy led to simultaneous cure of diarrhoea and cryptosporidiosis. Our findings in patients 3 and 4 show that they had a secretory diarrhoea: on fasting, high stool outputs persisted and the osmolality of faecal water was almost entirely accounted for by sodium, potassium, and their accompanying anions. We have shown in patient 3 that the secretion took place in the proximal small bowel, whereas the ileum and colon reabsorbed important amounts of fluid.

The pathophysiology of the secretory diarrhoea and malabsorption syndrome induced by this parasite in AIDS remains speculative: (1) no major abnormality of villous architecture was found, but the presence of numerous Cryptosporidia within the brush border (with microvilli loss and displacement) of otherwise well preserved enterocytes might impair transport through the apical pole of the cells. (2) The synthesis by the parasites of an intestinal secretagogue is an interesting possibility. Protozoans are known to contain hormone-like materials and neurotransmitters ${ }^{34}$ which are able to stimulate intestinal secretion ${ }^{35} 36$ and might exert here a paracrine effect. Very recently lysates of Entamoeba histolytica were shown to produce intestinal secretion probably mediated by serotonin. ${ }^{37}$

The role of other pathogens in the mechanism of our patients' diarrhoea is unlikely: Giardia lamblia and Candida albicans were eradicated without any improvement of the diarrhoea. Small intestinal bacterial overgrowth was probably not involved in the malabsorption syndrome as (1) patient 2 had a normal bacterial count in the jejunal fluid, and patient 4 a normal glucose breath test; (2) they all received almost continuous oral antibiotics and/or sulphonamides when malabsorption was documented. Finally, CMV gastrointestinal infection has been reported in AIDS, ${ }^{38} 39$ but not found in our patients' gut biopsy samples.

In conclusion diarrhoea and malabsorption represent severe and often intractable manifestations of AIDS in which intestinal parasites probably play a major role. In our experience, only Isospora belli can be cured (at least transiently) with some benefit for the patient. Total parenteral nutrition is presently the only therapeutic possiblity especially for the secretory diarrhoea of cryptosporidiosis. It has to be maintained usually until the patient' death as in cases 1,3 , and 4 .

The authors wish to thank P Ravisse for his help in identification of the Microsporidia and F Bernard, A Gaste, B Regnier and C Sanchez for their excellent technical help. The authors are grateful to $\mathrm{V} \mathrm{G}$ Levy, W Rosenbaum, B Vernisse and J P Marie for referring the patients.

\section{References}

1 Malebranche R, Arnoux E, Guerin JM et al. Acquired immunodeficiency syndrome with severe gastrointestinal manifestations in Haiti. Lancet 1983; 2: 873-8.

2 Pape JW, Liautaud B, Thomas F et al. Characteristics of the acquired immunodeficiency syndrome (AIDS) in Haiti. $N$ Engl J Med 1983; 309: 945-50.

3 Current WL, Reese NC, Ernest JV, Bailey WS, Heyman MB, Weinstein WM. Human cryptosporidiosis in immunocompetent and immuno- 
deficient persons. $N$ Engl J Med 1983; 308: 1252-7.

4 Levine ND, Corliss JO, Cox FEG et al. A newly revised classification of the protozooa. J Protozool 1980; 27: 37-58.

5 Vàvra J, Canning EU, Barker RJ, Desportes I. Characters of microsporidian genera. Parasitology 1981; 82: 131-42.

6 Andreani T, Modigliani R, Lecharpentier $\mathrm{Y}$ et al. Acquired immunodeficiency with intestinal cryptosporidiosis: possible transmission by Haitian whole blood. Lancet 1983; 1: 1187-91.

7 Henrisksen SA, Polhenz JF. Staining of Cryptosporidia by a modified Ziehl-Neelsen technique. Acta Vet Scand 1981; 22: 594-6.

8 Ruskoné A, René E, Chayvialle JA et al. Effect of somatostatin on diarrhea and on small intestinal water and electrolyte transport in a patient with pancreatic cholera. Dig Dis Sci 1982; 27: 459-65.

9 Curran JW. AIDS - two years later. $N$ Engl J Med 1983; 309: 609-11.

10 Clumeck N, Mascart-Lemone F, De Maubeuge J, Brenez D, Marcelis L. Acquired immune deficiency syndrome in black Africans. Lancet 1983; 1: 642.

11 Gillin JS, Urmacher C, West R, Shike M. Disseminated Mycobacterium avium - intracellulare infection in acquired immunodeficiency syndrome mimicking Whipple's disease. Gastroenterology 1983; 85: 1187-91.

12 Kudo RR. Protozoology, Springfield: Charles C Thomas, 1966: 807-21.

13 Shadduck JA, Pakes SP. Encephalitozoonosis (nosematosis) and toxoplasmosis. Am J Pathol 1971; 64: 657-71.

14 Weiser J. On the taxonomic position of the genus Encephalitozoon levatidi, Nicolau \& Shoen, 1923 (Protozoa: Microsporidia). Parasitology 1964; 54: 749_ 51.

15 Petri M. Studies on Nosema cuniculi found in transplantable ascites tumours with a survey of microsporidiosis in mammals. Acta Pathol Microbiol Scand 1969; suppl. 204: 1-91.

16 Sprague V. Nosema connori N. sp., a microsporidian parasite of man. Trans Am Microsc Soc 1974; 93: 400-2.

17 Torres CM. Morphologie d'un nouveau parasite de l'homme, Encephalitozoon chagasi, N. sp., observé dans un cas de meningo-encéphalo-myélite congénitale avec myosite et myocardite. CR Soc Biol 1927; 97: $1787-90$

18 Coulon C. Présence d'un nouvel Encephalitozoon (Encephalitozoon brumpti $\mathrm{n}$. sp) dans le liquide céphalorachidien d'un sujet atteint de méningite suraigue. Ann Parasitol Hum Comp 1929; 7: 449-52.

19 Wolf A, Cowen D. Granulomatous encephalomyelitis due to an Encephalitozoon (encephalitozoic encephalomyelitis). Bull Neurol Inst New York 1937; 6: 306-71.

20 Matsubayashi $\mathrm{H}$, Koike T, Mikata I, Takei H, Hagiwara S. A case of Encephalitozoon like body infection in man. Arch Pathol 1959; 67: 181-7.

21 Marcus PB, Vand der Wolt JJ, Burger PJ. Human tumor microsporidiosis. First reported case. Arch
Pathol 1973; 95: 341-3.

22 Margileth AM, Strano AJ, Chandra R, Neafic R, Blum M, Mc Cully RM. Disseminated nosematosis in an immunologically compromised infant. Arch Pathol 1973; 95: 145-50.

23 Ashton N, Wirasinha PA. Encephalitozoonosis (Nosematosis) of the cornea. Br J Ophthal 1973; 57: 669-74.

24 Pakes SP, Shadduck JA, Coli A. Fine structure of Encephalitozoon cuniculi from rabbits, mice and hamsters. J Protozool 1975; 22: 481-8.

25 Brandborg LL, Goldberg SB, Breidenbach WC. Human coccidiosis. A possible cause of malabsorption. The life cycle in small-bowel mucosa biopsies as a diagnostic feature. $N$ Engl J Med 1970; 283: 1306-13.

26 Gottlieb MS, Groopman JE, Weinstein WM, Fahey J, Detels $\mathbf{R}$. The acquired immunodeficiency syndrome. Ann Intern Med 1983; 99: 208-20.

27 Pitchenick AE, Fischl MA, Dickinson GM et al. Opportunistic infections and Kaposi's sarcoma among Haitians: evidence of a new acquired immunodeficiency state. Ann Intern Med 1983; 98: 277-84.

28 Meisel JL, Perera DR, Meligro C, Rubin CE. Overwhelming watery diarrhea associated with a Cryptosporidium in an immunosupressed patient. Gastroenterology 1976; 70: 1156-60.

29 Weinstein L, Edelstein SM, Madara JL, Falchuk KR, Mc Manus BM, Trier JS. Intestinal cryptosporidiosis complicated by disseminated cytomegalovirus infection. Gastroenterology 1981; 81: 584-91.

30 Sloper KS, Dourmashkin RR, Bird RB, Slavin G, Webster ADB. Chronic malabsorption due to cryptosporidiosis in a child with immunoglobulin deficiency. Gut 1982; 23: 80-2.

31 Center for Disease Control. Cryptosporidiosis: assessment of chemotherapy of males with acquired immune deficiency syndrome (AIDS). Morbid Mortal Weekly Rep 1982; 31: 589-92.

32 Current WL. Human cryptosporidiosis [Letter]. $N$ Engl J Med 1983; 309: 1326-7.

33 Jokiph L, Pohjola S, Jokiph AMM. Cryptosporidium: a frequent finding in patients with gastrointestinal symptoms. Lancet $1983 ; 2$ : $358-61$.

34 Roth J, Leroith D, Shiloack J, Rosenzweig JL, Lesniak MA, Havrankova J. The evolutionary origins of hormones, neurotransmitters, and other extracellular chemical messengers. $N$ Engl J Med 1982; 306: 523-7.

35 Modigliani R, Bernier JJ, Matuchansky C, Rambaud JC. Intestinal and electrolyte transport in man under the effect of exogenous hormones of the gut and prostaglandins and in patients with endocrine tumors of the pancreas. In: Jerzy Glass GB, ed. Progress in gastroenterology, vol III. New York: Grune and Stratton, 1977: 285-319.

36 Isaacs PET, Corbett Cl, Riley AK, Hawker PC, Turnberg LA. In vitro behaviour of human intestinal mucosa. The influence of acetylcholine on ion transport. J Clin Invest 1976; 58: 535-42.

37 Mc Gowan K; Kane A, Asarkof N, Wicks J, Guerina V. Entamoeba histolytica causes intestinal secretion: role of serotonin. Science 1983; 221: 762-4.

38 Knapp AB, Horst DA, Eliopoulos G et al. Widespread 
cytomegalovirus gastroenterocolitis in a patient with acquired immunodeficiency syndrome. Gastroenterology 1983; 85: 1399-402.

39 Gertler SL, Pressman J, Price P, Brozinsky S, Miyai K.
Gastrointestinal cytomegalovirus infection in a homosexual man with severe acquired immunodeficiency syndrome. Gastroenterology 1983; 85: 14036 . 